\title{
Tobramycin Adenylyltransferase: A New Aminoglycoside- Inactivating Enzyme from Staphylococcus epidermidis
}

\author{
Partha Santanam and Fritz H. Kayser
}

From the Institute of Medical Microbiology, University of Zurich, Zurich, Switzerland

\begin{abstract}
Certain strains of Staphylococcus epidermidis resistant to the aminoglycoside antibiotics were shown to contain an enzyme that inactivates the kanamycins, neomycins, butirosins, paromomycin, gentamicin $\mathrm{A}$, amikacin, and tobramycin by adenylylation. Tobramycin adenylyltransferase, as this enzyme is called, was found to be optimally active at $\mathrm{pH} 5.5$. With paromomycin or neomycin $\mathrm{B}$ and $\mathrm{C}$ as substrates, however, two $\mathrm{pH}$ values (5.5 and 9.0) for optimal activity were observed. The enzyme requires $\mathrm{Mg}^{+}+$for activity and is stabilized significantly by dithiothreitol. It is probable that the 4'-hydroxyl group of ring I of the antibiotics is adenylylated. Those aminoglycosides that are not substrates for the enzyme lack a hydroxyl group in the corresponding position.
\end{abstract}

An epidemiological study of the frequency of resistance of staphylococci to aminoglycosides showed that $2 \%$ of isolates of Staphylococcus epidermidis were inhibited by $\geqslant 12.5 \mu \mathrm{g}$ of tobramycin/ml. Such tobramycin-resistant $\left(\mathrm{Tm}^{\mathrm{R}}\right)$ strains were also resistant to kanamycin $\mathrm{A}$, paromomycin, butirosin, and gentamycin $\mathrm{A}$ and intermediately resistant to neomycin and amikacin. In a genetic study of $\mathrm{Tm}^{\mathrm{R}}$ in such strains, it was found that resistance was conferred by a small plasmid (mol wt, $2.7 \times 10^{6}$ daltons) present in multiple copies [1]. Loss of this plasmid resulted in tobramycin-susceptible variants, which were also susceptible to the other aminoglycosides except streptomycin.

We now report that the mechanism of resistance to aminoglycosides in these staphylococci can be explained by the production of an adenylylating enzyme. We propose to call this enzyme by the trivial name tobramycin adenylyltransferase, because it was detected in staphylococci unusually resistant to tobramycin, and tobramycin was found to be one of the best substrates for it.

\section{Materials and Methods}

Antibiotics and chemicals. Tobramycin was supplied by Eli Lilly and Company (India-

Please address requests for reprints to Dr. F. H. Kayser, Institute of Medical Microbiology, 8028 Zurich, Switzerland. napolis, Ind.); the kanamycins $\mathrm{A}, \mathrm{B}$, and $\mathrm{C}$, amikacin (BB-K8), and butirosin by Bristol Laboratories (Syracuse, N.Y.); neomycins B and $\mathrm{C}$ and spectinomycin by the Upjohn Co. (Kalamazoo, Mich.); paromomycin by Parke, Davis and Co. (Detroit, Mich.); and the gentamicins $\mathrm{C}_{1}, \mathrm{C}_{2}, \mathrm{C}_{1 \mathrm{a}}$, and $\mathrm{A}$ and sisomicin by Schering Corp. (Bloomfield, N.J.). The other antimicrobial agents were provided by the pharmacy of the University Hospital (Zurich, Switzerland).

Radiolabeled chemicals were bought from the Radiochemical Centre (Amersham, England). Dithiothreitol and adenosine triphosphate (ATP) were obtained from Calbiochem (Los Angeles, Calif.). All other inorganic salts of analytic grade were obtained from Merck (Darmstadt, Federal Republic of Germany).

Organism. The representative strain used for our studies was $S$. epidermidis strain 109 , which was isolated from clinical material obtained in Zurich. In addition to tobramycin, this strain is resistant to penicillin $\left(\mathbf{P e n}^{\mathrm{R}}\right)$, chloramphenicol $\left(\mathrm{Cm}^{\mathrm{R}}\right)$, tetracycline $\left(\mathrm{Tc}^{\mathrm{R}}\right)$, streptomycin $\left(\mathrm{Sm}^{\mathrm{R}}\right)$, and sulfamethoxazole $\left(\mathrm{SMZ}^{\mathrm{R}}\right)$ and is moderately resistant to methicillin $\left(\right.$ Meth $\left.^{\mathbf{R}}\right)$. The organism was maintained on brain-heart infusion agar (Difco, Detroit, Mich.) containing $20 \mu \mathrm{g}$ of neomy$\mathrm{cin} / \mathrm{ml}$. For production of enzyme, the strain was subcultured on brain-heart infusion agar containing $10 \mu \mathrm{g}$ of neomycin $\mathrm{B} / \mathrm{ml}$. The culture was inoculated into $2 \mathrm{ml}$ of a medium composed of Bacto-tryptone (Difco), $10 \mathrm{~g}$; Bacto-yeast extract 
(Difco), $50 \mathrm{~g} ; \mathrm{NaCl}, 10 \mathrm{~g}$; glucose, $4 \mathrm{~g}$; and an amount of water sufficient to make 1 liter. The $\mathrm{pH}$ was adjusted to 7.2. For growth of the inoculum, this medium contained $10 \mu \mathrm{g}$ of neomycin $\mathrm{B} / \mathrm{ml}$. After overnight incubation, $1 \mathrm{ml}$ of the inoculum was inoculated into $100 \mathrm{ml}$ of fresh medium, which was incubated in a shaking water bath at $37 \mathrm{C}$. At the beginning of the exponential phase of growth, $1 \mathrm{ml}$ of neomycin B $(400 \mu \mathrm{g} /$ $\mathrm{ml}$ ) was added to the culture. When the culture reached an OD of about 1 at $550 \mathrm{~nm}$, cells were harvested by centrifugation at $11,000 \mathrm{~g}$ for $10 \mathrm{~min}$ at $4 \mathrm{C}$ and were washed twice with $40 \mathrm{ml}$ of a cold buffer containing $0.01 \mathrm{M}$ Tris and $0.03 \mathrm{M}$ $\mathrm{NaCl}$ ( $\mathrm{pH} 7.8$ ).

Production of enzyme. The osmotic shock method [2], slightly modified, was used. The washed cells were suspended in $10 \mathrm{ml}$ of $0.033 \mathrm{M}$ Tris- $\mathrm{HCl}$ buffer $(\mathrm{pH} 7.3$ ) containing $0.003 \mathrm{M}$ EDTA and 20\% sucrose. After it stood at room temperature (about $20 \mathrm{C}$ ) for $30 \mathrm{~min}$, the suspension was stirred with a magnetic stirrer for $5 \mathrm{~min}$ and centrifuged for $15 \mathrm{~min}$ at $12,000 \mathrm{~g}$ and $4 \mathrm{C}$. The supernatant was discarded, and the remaining sucrose was removed carefully from the wall of the centrifuge tubes with cotton swabs. The pellet of cells was suspended in $5 \mathrm{ml}$ of an ice-cold solution of $0.0005 \mathrm{M} \mathrm{MgCl}_{2}$, and the suspension was aspirated forcefully about 20 times with a $5-\mathrm{ml}$ pipette. After stirring for $5 \mathrm{~min}$ and centrifugation for $15 \mathrm{~min}(22,000 \mathrm{~g})$ at $4 \mathrm{C}$, the supernatant was carefully decanted to a flask containing $150 \mu \mathrm{l}$ of a $0.04 \mathrm{M}$ solution of dithiothreitol.

For preparation of extracts by sonification, the washed cells were suspended in an ice-cold solution of $0.0005 \mathrm{M} \mathrm{MgCl}_{2}$, frozen at $-70 \mathrm{C}$, thawed rapidly, and sonified for $3 \mathrm{~min}$ at $55 \mathrm{~W}$ (Branson sonifier B-12; Branson, Danbury, Conn.). The procedure was repeated once, after which the suspension was centrifuged for $15 \mathrm{~min}$ at $22,000 \mathrm{~g}$ at $4 \mathrm{C}$. The supernatant was decanted and stabilized with dithiothreitol.

For preparation of lysates, cells were lysed by lysostaphin according to procedures described by Shaw and Brodsky [3].

Enzymatic assay. The methods used were similar to those described by Benveniste et al. [4] and to those by Davies et al. [5]. The assay for adenylylation consisted of $20 \mu \mathrm{l}$ of cell extract
(0.5-1.0 mg of protein $/ \mathrm{ml}), 1.5 \mu \mathrm{mol}$ of buffer, 0.5-0.7 $\mu \mathrm{mol}$ of $\mathrm{MgCl}_{2}, 55 \mathrm{nmol}$ of dithiothreitol, $20 \mathrm{nmol}$ of $\left[2-{ }^{3} \mathrm{H}\right] \mathrm{ATP}$ (specific activity, 60 $\mu \mathrm{Ci} / \mu \mathrm{mol}$ ), and $0.6-0.8 \mathrm{nmol}$ of drug base (total volume, $65 \mu \mathrm{l})$. After incubation at $35 \mathrm{C}$ for various periods, $50-\mu \mathrm{l}$ samples were pipetted onto a 2-cm² phosphocellulose paper (Whatman P-81; Balsbon, Maidstone, England), which was washed twice with double-distilled water and dried at $55 \mathrm{C}$. Radioactivity was counted in a Packard Tri-Carb scintillation spectrometer (Packard Instruments, Downers Grove, IIl.) in $10 \mathrm{ml}$ of a toluene-based scintillation fluid. Reaction mixtures devoid of either the enzyme or the drug were used as controls for nonspecific binding of $\left[2{ }^{3} \mathrm{H}\right] \mathrm{ATP}$. When adenylylation had to be measured before completion of the reaction, the tubes containing the reaction mixtures were chilled in ice-water for termination of the reaction. The amount of drug used in all experiments was within the linear range of a quantitative assay.

Acetylating and phosphorylating activities in the cell extract were checked according to methods described by Haas and Davies [6] and Benveniste and Davies [7].

Assays for inactivation of drugs. After completion of the reaction, $50 \mu \mathrm{l}$ of the reaction mixture containing the ingredients mentioned above were placed in wells punched in antibiotic agar no. 3 (Difco) containing $10^{4}$ spores of Bacillus subtilis (ATCC 6633 ) $/ \mathrm{ml}$ as the test organism, and inactivation of drugs was checked. After incubation at $30 \mathrm{C}$ for $24 \mathrm{hr}$, the degree of inactivation was measured by comparison of the zones of inhibition with appropriate controls.

MIC of drugs. The MIC of antibiotics was determined in Mueller-Hinton broth (Baltimore Biological Laboratories, Baltimore, Md.) [8].

Protein assay. The protein content of cell extracts was measured by the method of Lowry et al. [9].

\section{Results}

Enzymatic inactivation of aminoglycosides. Natural resistance to aminoglycosides in grampositive and gram-negative bacteria is usually the result of a chemical modification and the consequent inactivation of the antibiotics by certain enzymes [10]. Since the known aminoglycoside- 
inactivating enzymes are periplasmic enzymes and are released from $\mathrm{R}$-factor-containing gramnegative bacteria by osmotic shock [2], the same procedure was used for extraction of the enzyme from $S$. epidermidis strain 109.

Those drugs that are substrates for the enzyme were inactivated when the reaction mixture contained ATP. No inactivation was observed when the reaction mixture contained either acetyl coenzyme A or cell extracts from tobramycinsusceptible variants. All of the drugs except gentamicins $\mathrm{C}_{1 \mathrm{a}}, \mathrm{C}_{2}$, and $\mathrm{C}_{3}$, sisomycin, streptomycin, and spectinomycin were inactivated (table 1).

Adenylylation of aminoglycosides. Since ATP was required for inactivation of the enzyme, we assumed that the antibiotics were modified either by O-adenylylation or O-phosphorylation. No transfer of radioactivity from $\left[\gamma^{-32}\right.$ P]ATP to the aminoglycosides was detectable in the enzymatic assay. Radioactivity was, however, transferred to the drugs from $\left[2-{ }^{3} \mathrm{H}\right] \mathrm{ATP}$. The optimal $\mathrm{pH}$ for

Table 1. Effects of adenosine triphosphate (ATP) and acetyl coenzyme A (acetyl CoA) on inactivation of aminoglycoside antibiotics by lysates of osmotically shocked Staphylococcus epidermidis strain 109.

\begin{tabular}{|c|c|c|c|c|}
\hline \multirow[b]{2}{*}{ Antibiotic } & \multicolumn{3}{|c|}{ Strain 109 plus } & \multirow{2}{*}{$\begin{array}{c}\text { Strain } \\
109\left(\mathrm{Tm}^{\mathrm{S}}\right) \\
\text { plus ATP } \dagger\end{array}$} \\
\hline & ATP & $\begin{array}{c}\text { Acetyl } \\
\text { CoA }\end{array}$ & Buffer* & \\
\hline Tobramycin & + & - & - & - \\
\hline Neomycin B & + & - & - & 一 \\
\hline Butirosin & + & - & - & - \\
\hline Kanamycin A & + & - & - & - \\
\hline Gentamicin A & + & - & - & - \\
\hline Paromomycin & + & - & - & - \\
\hline Amikacin & + & - & - & - \\
\hline \multicolumn{5}{|l|}{ Gentamicins } \\
\hline $\mathrm{C}_{1 \mathrm{a}}, \mathrm{C}_{1}, \mathrm{C}_{2}$ & - & - & - & - \\
\hline Sisomicin & - & - & - & - \\
\hline Streptomycin & - & - & - & - \\
\hline Spectinomycin & - & - & - & - \\
\hline
\end{tabular}

Note. Inactivation was determined by the agar diffusion test as described in Materials and Methods. A plus sign indicates that the antibiotics were inactivated; a minus sign indicates no inactivation in comparison with results in appropriate controls. Unlabeled ATP ( $20 \mathrm{nmol}$ ) or unlabeled acetyl $\mathrm{COA}$ (10 $\mathrm{nmol})$ was used in each assay.

* The buffer used was Tris-maleate (pH 5.5).

† Strain $109\left(\mathrm{Tm}^{\mathrm{S}}\right)$ is a spontaneous, tobramycin-susceptible variant of strain 109 .

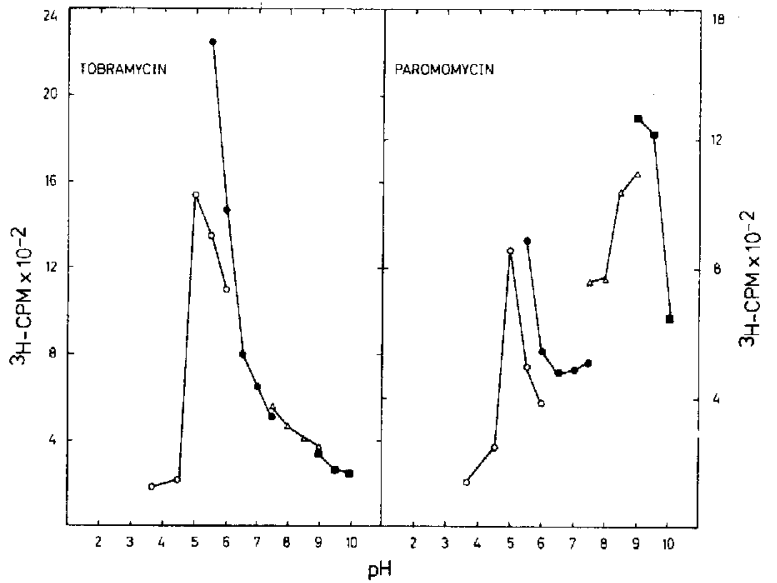

Figure 1. $\mathrm{pH}$ dependence of adenylylation reaction with tobramycin adenylyltransferase. Reaction mixtures were prepared at the indicated $\mathrm{pH}$ values with use of appropriate buffers. $(\mathrm{O}-\mathrm{O})=$ citratephosphate buffer, pH 3.8-6.0; ( - ) = Trismaleate buffer, $\mathrm{pH}$ 5.5-7.5; $(\triangle \longrightarrow \triangle)=$ barbital buffer, $\mathrm{pH} \quad 7.5-9.0 ;$ ( $\square)=$ glycine- $\mathrm{NaOH}$ buffer, $\mathrm{pH}$ 9.0-10.0. Incubation at $35 \mathrm{C}$ lasted for $2.5 \mathrm{~min}$ with tobramycin and for $9 \mathrm{~min}$ with paromomycin. These periods of incubation were in the linear range of assay at the indicated $\mathrm{pH}$ values.

enzymatic reaction with tobramycin, kanamycin $\mathrm{A}, \mathrm{B}$, and $\mathrm{C}$, the butirosins, and gentamicin $\mathrm{A}$ was 5.5 ; with amikacin it was 6.0 , although adenylylation occurred over a broad range of $\mathrm{pH}$ (4.5-9.5). Adenylylation of paromomycin, neomycin $\mathrm{B}$, and neomycin $\mathrm{C}$ had two $\mathrm{pH}$ optima, 5.5 and 9.0 (figure 1 ).

The efficiencies of adenylylation of the different aminoglycosides by tobramycin adenylytransferase at $\mathrm{pH} 5.5$ are listed in table 2 . It can be seen that this enzyme is different from both streptomycin-spectinomycin adenylyltransferase and gentamicin adenylyltransferase, since streptomycin and spectinomycin, the gentamicins $\mathrm{C}_{1 a}, \mathrm{C}_{1}$, and $\mathrm{C}_{2}$, and sisomicin are not adenylylated [10].

At pH 5.5, tobramycin is one of the best substrates, whereas amikacin is a rather poor one. In general, the efficiency data reflect the phenotypic resistance of strain 109 , except in the case of neomycin B, which is readily adenylylated but weakly inhibitory to the strain. Adenylylation therefore may inactivate the drug incompletely, an effect resulting in a low MIC value.

When the kinetics of adenylylation were examined, it was found that some antibiotics were 
Table 2. Adenylylation of aminoglycoside antibiotics by cell-free extracts of Staphylococcus epidermidis strain 109.

\begin{tabular}{|c|c|c|c|}
\hline Antibiotic & $\begin{array}{c}{[2-3 \mathrm{H}] \mathrm{ATP}} \\
\text { incorporated } \\
(\mathrm{cpm})^{*}\end{array}$ & $\begin{array}{c}\text { Percentage } \\
\text { of ATP } \\
\text { incorporated }\end{array}$ & $\begin{array}{c}\text { MIC } \\
(\mu \mathrm{g} / \mathrm{ml})^{\dagger}\end{array}$ \\
\hline Kanamycin B & 3,750 & 127 & 200 \\
\hline Neomycin C & 3,625 & 123 & 100 \\
\hline Tobramycin & 2,950 & 100 & 100 \\
\hline Neomycin B & 2,425 & 82 & 6.25 \\
\hline Kanamycin C & 1,650 & 56 & 400 \\
\hline Butirosin & 1,500 & 51 & 200 \\
\hline Kanamycin A & 1,450 & 49 & 100 \\
\hline Gentamicin A & 1,200 & 41 & 400 \\
\hline Paromomycin & 1,000 & 34 & 100 \\
\hline Amikacin & 425 & 14 & 6.25 \\
\hline Gentamicin $C_{1 \mathrm{a}}$ & 237 & 0 & $<0.047$ \\
\hline Gentamicin $C_{2}^{18}$ & 168 & 0 & $<0.047$ \\
\hline Gentamicin $C_{1}$ & 223 & 0 & $<0.047$ \\
\hline Sisomicin & 172 & 0 & $<0.047$ \\
\hline Streptomycin & 203 & 0 & $>400$ \\
\hline Spectinomycin & 222 & $\mathbf{0}$ & 25 \\
\hline None & 230 & 0 & \\
\hline
\end{tabular}

* ATP $=$ adenosine triphosphate. The assays were performed as described in Materials and Methods. Samples were incubated for $6 \mathrm{~min}$ with all substrates to ensure an assay in the linear range. Efficiency of adenylylation was calculated with reference to radioactivity of the adenylylated tobramycin. A count of $2,950 \mathrm{cpm} / \mathrm{min}$ was equated with $100 \%$ efficiency. Controls devoid of either enzyme or drug had an average value of $230 \mathrm{cpm}$.

$\dagger$ MICs of drugs were determined in Mueller-Hinton broth [8].

adenylylated at approximately the same rate but not to the same extent (figure 2). A possible explanation for this behavior is that the end products differ slightly in ability to inhibit the enzymatic reaction. However, such inhibition does not seem to be a major factor in determining levels of resistance in intact bacteria (table 2).

Properties of tobramycin adenylyltransferase. Of the three methods tested, osmotic shock yields a preparation with the highest enzymatic activity. Like other aminoglycoside-inactivating enzymes, the enzyme has an absolute requirement for $\mathrm{Mg}^{++}$ions. Dithiothreitol stabilizes the enzyme significantly. The transferase is stable for at least 60 days when stored at $-40 \mathrm{C}$ in the presence of dithiothreitol. Nearly $90 \%$ of activity was lost after storage for 60 days at $4 \mathrm{C}$ and for one week at $22 \mathrm{C}$ (table 3 ).

\section{Discussion}

In recent years it has become apparent that, under some circumstances, $S$. epidermidis can be considered to be as pathogenic as Staphylococcus aureus. Certain infections, such as endocarditis, urinary tract infections, and colonization of ventriculoatrial shunts are typically caused by S. epidermidis [11-14]. In addition, this organism can sometimes be isolated in pure culture from pyogenic material. The isolated bacteria often prove to be quite resistant to antibiotics [15-17]. Resistance to all $\beta$-lactam antibiotics, to the tetracyclines, to erythromycin, streptomycin, and the sulfonamides, and often also to kanamycin, neomycin, and chloramphenicol has been demonstrated [18]. Thus the new aminoglycoside antibiotics may become significant aids in the treatment of staphylococcal infections.

However, we have found that some $S$. epidermidis strains are resistant to multiple drugs, including many of the new aminoglycoside antibiotics. A previous genetic study revealed that the determinants of resistance to aminoglycosides in representative strains of these staphylococci are plasmid-borne and can be transduced between

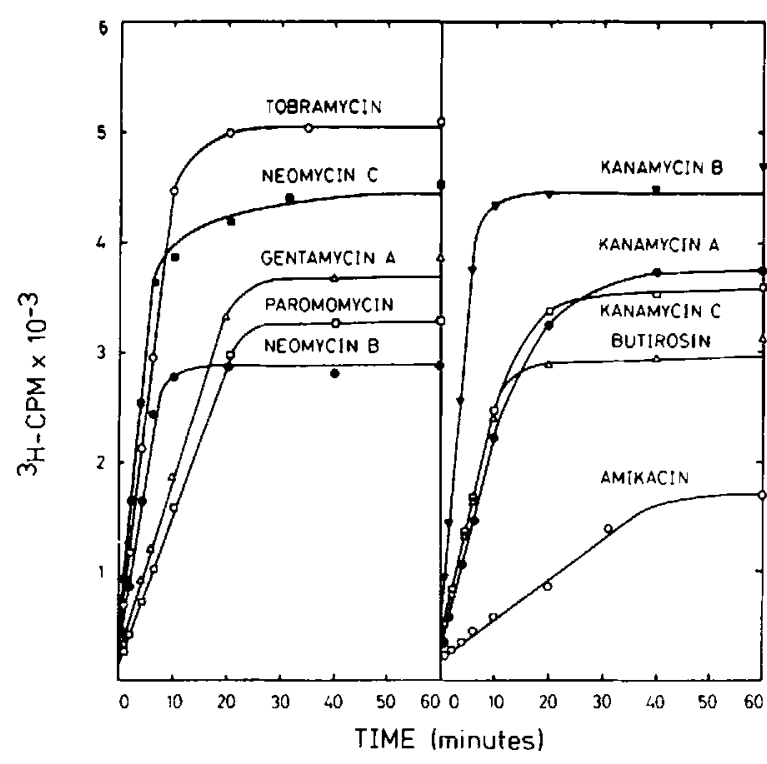

Figure 2. Kinetics of adenylylation of various aminoglycoside antibiotics. Samples were incubated at $35 \mathrm{C}$ for various periods, after which $50-\mu \mathrm{l}$ portions were pipetted onto a phosphocellulose paper which was washed and counted for radioactivity. 
Table 3. Properties of tobramycin adenylyltransferase.

\begin{tabular}{|c|c|c|c|}
\hline \multirow{2}{*}{ Property } & \multicolumn{3}{|c|}{$\begin{array}{l}\text { Adenylylation } \\
(\%)^{*}\end{array}$} \\
\hline & \\
\hline Osmotic lysate $(0.5 \mathrm{mg}$ of protein $/ \mathrm{ml})$ & & 100 & \\
\hline Sonified extract $(1.0 \mathrm{mg}$ of protein $/ \mathrm{ml})$ & & 54 & \\
\hline Lysed extract $(2.9 \mathrm{mg}$ of protein $/ \mathrm{ml})$ & & 11 & \\
\hline \multicolumn{4}{|l|}{$\mathbf{M g}++$ requirement (per assay) $\ddagger$} \\
\hline None & & 4 & \\
\hline $0.05 \mu \mathrm{mol}$ & & 33 & \\
\hline $0.1 \mu \mathrm{mol}$ & & 64 & \\
\hline $0.3 \mu \mathrm{mol}$ & & 88 & \\
\hline $0.5 \mu \mathrm{mol}$ & & 97 & \\
\hline $0.7 \mu \mathrm{mol}$ & & 100 & \\
\hline $1.0 \mu \mathrm{mol}$ & & 95 & \\
\hline $2.0 \mu \mathrm{mol}$ & & 91 & \\
\hline \multicolumn{4}{|l|}{ Dithiothreitol requirement (per assay) } \\
\hline None & & 44 & \\
\hline $55 \mathrm{nmol}$ & & 100 & \\
\hline \multicolumn{4}{|l|}{ Stability (days) $\dagger$} \\
\hline 0 & 100 & 100 & 100 \\
\hline 1 & 100 & 100 & 87 \\
\hline 6 & 100 & 100 & 61 \\
\hline 7 & 100 & 100 & 11 \\
\hline 20 & 100 & 87 & 0 \\
\hline 30 & 100 & 80 & 0 \\
\hline 60 & 100 & 9 & 0 \\
\hline
\end{tabular}

* Adenylylation values listed in relation to the property of stability were obtained at $-40 \mathrm{C}, 4 \mathrm{C}$, and $22 \mathrm{C}$, respectively.

$\dagger$ Activity was measured after incubation for $30 \mathrm{~min}$ at $35 \mathrm{C}$, with neomycin $\mathrm{B}$ as substrate, in Tris- $\mathrm{HCl}$ buffer (pH 8.0). A count of $3,658 / \mathrm{min}$ was equated with $100 \%$ activity.

$\ddagger$ Activity was measured after incubation for $15 \mathrm{~min}$ at $35 \mathrm{C}$, with tobramycin as substrate, in Tris-maleate buffer (pH 5.5). A count of $5,276 / \mathrm{min}$ was equated with $100 \%$ activity.

$\S$ Activity was measured after incubation for $6 \mathrm{~min}$ at $35 \mathrm{C}$, with neomycin B as substrate, in Tris-maleate buffer (pH 5.5). A count of $3,884 / \mathrm{min}$ was equated with $100 \%$ activity.

strains with rather high frequency [1]. The size and other characteristics of this extrachromosomal element are not unusual for staphylococci [1]. However, the plasmid is unusual, insofar as it carries the determinants for production of an aminoglycoside-inactivating enzyme with a broad range of activity. To our knowledge, an enzyme with the properties of tobramycin adenylyltransferase has not been found in either gram-positive or gram-negative bacteria.
Although the end products of enzymatic reaction are yet to be isolated and identified, the substrate profile strongly suggests that adenylylation occurs at the 4'-hydroxyl group of ring I of these antibiotics. The kanamycins, the neomycins, the butirosins, paromomycin, amikacin, gentamicin $\mathrm{A}$, and tobramycin all contain such a group in this position, whereas sisomicin and gentamicins $C_{1 a}, C_{1}$, and $C_{22}$ do not (figure 3). Except for butirosin, all of the substrates have yet another hydroxyl group that can be adenylylated (i.e., the 4"-hydroxyl group of ring III of tobramycin, gentamicin $\mathrm{A}$, the kananiycins, and amikacin, and the 4"'-hydroxyl group of ring IV of the neomycins and paromomycin. Whether or not this second hydroxyl group is also adenylylated remains to be determined after analysis of the adenylylated antibiotics.

The demonstration of a tobramycin adenylyltransferase that inactivates the classical aminoglycosides as well as some of the newer antibiotics of this group implies that no guarantees of freedom from resistance to antibiotics of the future can be given. Thus, although resistance to gentamicin has not been found in staphylococci isolated in our area despite use of the drug for a decade, it is perhaps only a matter of time before resistant strains appear. If such resistance is plasmid-borne, the widespread intraspecies and perhaps also interspecies distribution [19] of this plasmid under appropriate selective conditions in vivo might result. Therefore, an important aspect of antistaphylococcal chemotherapy in the future should be a restriction of the use of the new, highly potent antibiotics to cases in which these drugs are absolutely necessary.

\section{References}

1. Rosendorf, L. L., Kayser, F. H. Transduction and plasmid deoxyribonucleic acid analysis in a multiply antibiotic resistant strain of Staphylococcus epidermidis. J. Bacteriol. 120:679-686, 1974.

2. Neu, H. C., Heppel, L. A. The release of enzymes from Escherichia coli by osmotic shock and during the formation of spheroplasts. J. Biol. Chem. 240:3685-3692, 1965.

3. Shaw, W. V., Brodsky, R. F. Characterization of chloramphenicol-acetyltransferase from chloramphenicol-resistant Staphylococcus aureus. J. Bacteriol. 95:28-36, 1968. 
A

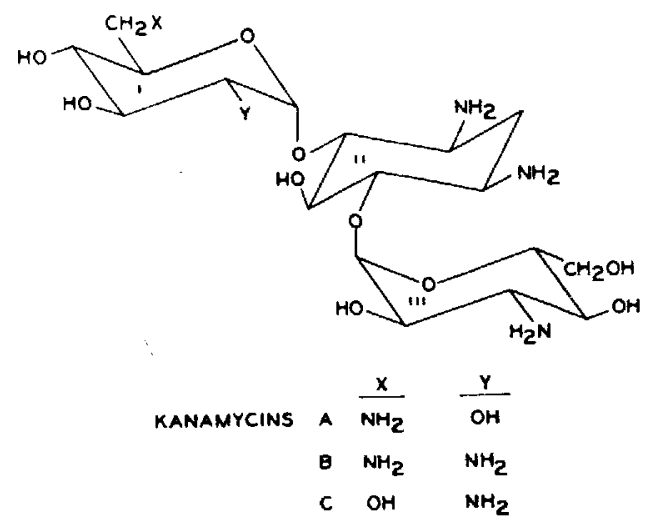

C

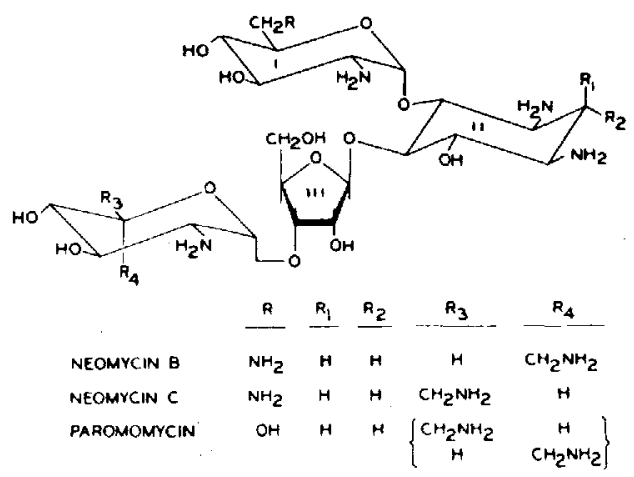

$B$

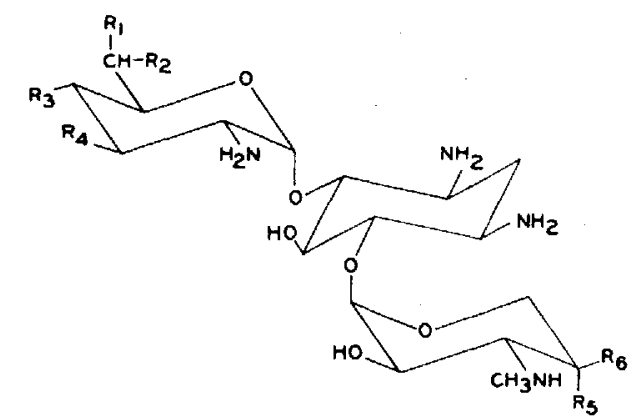

D

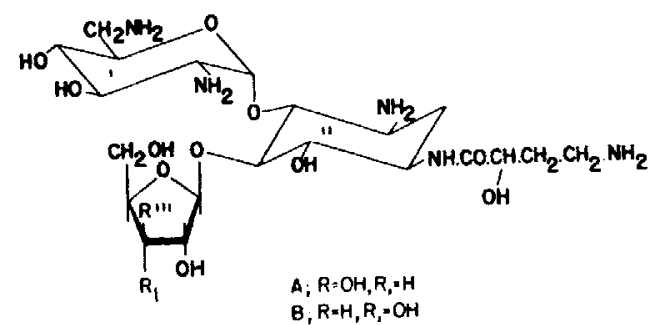

Figure 3. $A$, structure of kanamycins. Positions in ring I are numbered $1^{\prime}-6^{\prime} ;$ in ring II, 1-6; and in ring III, $1^{\prime \prime}-6^{\prime \prime}$. Position $\gamma$ is the $2^{\prime}$ position. Tobramycin is $3^{\prime}$-deoxykanamycin B. Amikacin is 1-hydroxyamino-butyrylkanamycin A. B, structure of gentamicins. Sisomicin is $4^{\prime}, 5^{\prime}$-dehydrogentamicin $C_{1 \mathrm{a}} \cdot C$, structure of neomycins. $D$, structure of butirosins.

4. Benveniste, R., Yamada, T., Davies, J. Enzymatic adenylylation of streptomycin and spectinomycin by R-factor resistant Escherichia coli. Infec. Immun. 1:109-119, 1970.

5. Davies, J., Brzezinska, M., Benveniste, R. R-factors: biochemical mechanism of resistance to aminoglycoside antibiotics. Ann. N.Y. Acad. Sci. 182: 226-233, 1971.

6. Haas, M. J., Davies, J. Enzymatic acetylation as a means of determining serum aminoglycoside concentrations. Antimicrob. Agents Chemother. 4:497-499, 1973.

7. Benveniste, R., Davies, J. Aminoglycoside antibioticinactivating enzymes in actinomycetes similar to those present in clinical isolates of antibioticresistant bacteria. Proc. Natl, Acad. Sci. U.S.A. 70:2276-2280, 1973.

8. Ericsson, H. M., Sherris, J. C. Antibiotic sensitivity testing: report of an international collaborative study. Acta Pathol. Microbiol. Scand. [B] 79 (Suppl. 217):1-90, 1971.
9. Lowry, O. H., Rosebrough, N. J., Farr, A. L. Randall, R. J. Protein measurement with the Folin phenol reagent. J. Biol. Chem. 193:265-275, 1951.

10. Benveniste, R., Davies, J. Mechanisms of antibiotic resistance in bacteria. Annu. Rev. Biochem. 42: 471-505, 1973.

11. Holt, R. J. The colonisation of ventriculo-atrial shunts by coagulase-negative staphylococci In M. Finland, W. Marget, and K. Bartmann [ed.]. Bayer Symposium III. Bacterial infections. Springer-Verlag, Berlin, 1971, p. 81-90.

12. Holt, R. J. Coagulase-negative staphylococci as opportunist pathogens. Arzneim. Forsch. 21:325-328, 1971.

13. Holt, R. J. The pathogenic role of coagulasenegative staphylococci. Br. J. Dermatol. 86 (Suppl. 8):42-47, 1972.

14. Keys, T. F., Hewitt, W. J. Endocarditis due to micrococci and Staphylococcus epidermidis. Arch. Intern. Med. 132:216-2.20, 1973. 
15. Andriole, V. T., Lyons, R. W. Coagulase-negative Staphylococcus. Ann. N.Y. Acad. Sci. 174:533544, 1970.

16. Bentley, D. W., Hahn, J. J., Lepper, M. H. Transmission of chloramphenicol-resistant Staphylococcus epidermidis: epidemiologic and laboratory studies. J. Infect. Dis. 122:365-375, 1970.

17. Marsik, F. J., Parisi, J. T. Significance of Staphylococcus epidermidis in the clinical laboratory. Appl.
Microbiol. 25:11-14, 1973.

18. Pulverer, G., Damen, G. Neugebauer, M. Antibiotic resistance of Staphylococcus albus. Med. Microbiol. Immunol. 158:32-43, 1972.

19. $\mathrm{Yu}$, L., Baldwin, J. N. Intraspecific transduction in Staphylococcus epidermidis and interspecific transduction between Staphylococcus aureus and Staphylococcus epidermidis. Can. J. Microbiol. 17:767-773, 1971. 